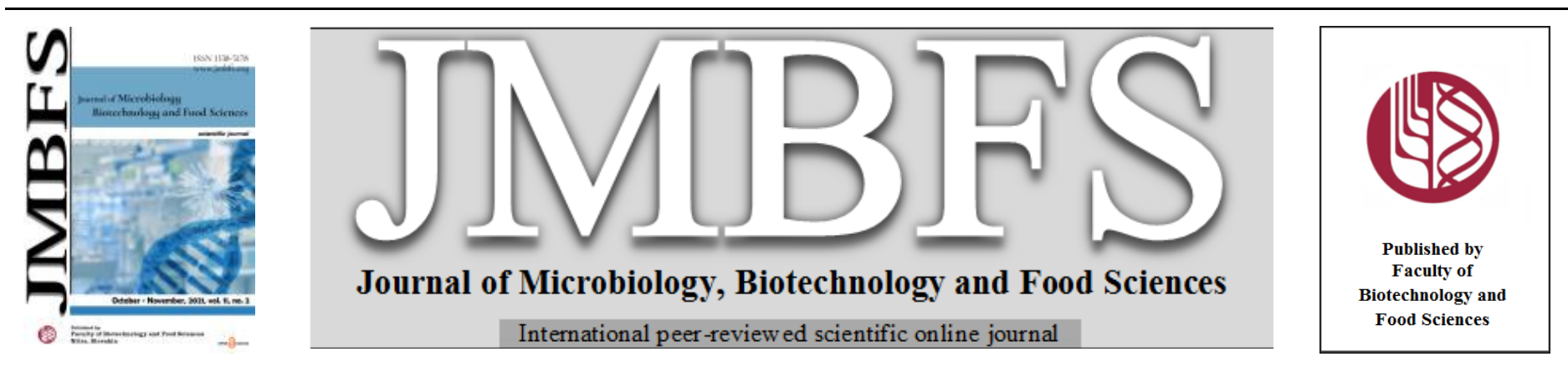

\title{
PHYSICOCHEMICAL, TEXTURAL AND ORGANOLEPTIC CHARACTERISTICS OF WEST AFRICAN STIFF DOUGH 'AMALA' MADE FROM SOAKED AND UNSOAKED COCOYAM FLOUR
}

\author{
Rahman Akinoso ${ }^{1}$, Adetunji Ismael Lawal ${ }^{* 1}$, Kazeem Koledoye Olatoye ${ }^{2}$, Dorcas Olawunmi Olayioye ${ }^{1}$
}

Address(es): Dr. Adetunji Ismael Lawal,

${ }^{1}$ Department of Food Technology, Faculty of Technology, University of Ibadan, Nigeria, +2348036245805 .

${ }^{2}$ Department of Food Science and Technology, Faculty of Agriculture, Kwara State University, Malete, P.M. B.1530, Ilorin, Kwara State, Nigeria.

*Corresponding author: tunjawal@gmail.com

https://doi.org/10.15414/jmbfs.3728

\section{ARTICLE INFO}

Received 18.9. 2020

Revised 24. 3. 2021

Accepted 8. 4. 2021

Published 1. 10. 2021

Regular article

OPEN $\partial_{\text {ACCESS }}$

\section{ABSTRACT}

Cocoyam is a nutrient dense but neglected tropical food crop. Conversion of its tubers into flour and West African stiff dough 'amala' (WASDA) - commonly produce from white yam flour, would enhance cocoyam utilization and reduce pressure on white yam. A $3 \mathrm{x} 2$ factorial experiment with 3 soaking period (0,12 and $24 \mathrm{~h}$ after peeling at ambient conditions $\left.30 \pm 2{ }^{\circ} \mathrm{C}\right)$ and 2 varieties (Colocasia spp. and Xanthosoma spp.) were used. The physicochemical, functional and pasting properties and sensory attributes of the flours and WASDA were analyzed. The soaking processes significantly $(\mathrm{p}<0.05)$ affected the physicochemical properties. Color $\left(\mathrm{L}^{*}\right.$ value), amylose and total starch contents of flours ranged from 66.68 to $76.52,11.22$ to $22.39 \%$ and 63.22 to $70.32 \%$, respectively. The variations in functional properties of the flours were species dependent. Soaked flour of Colocasia spp. (Col 12) showed significantly higher peak (5118.67 cp), holding strength (4102.67 cp) and final (6445.33 cp) viscosities than the others flours. Sensory attributes revealed that, the controlled WASDA from commercial yam flour had the best color, aroma, texture, mouldability, taste and overall acceptability, while WASDA from 12 (Colocasia spp.) and 24 (Xanthosoma spp.) h soaking showed higher overall acceptability and physical stability compared with the unsoaked products.

Keywords: cocoyam; soaking; stiff dough; physicochemical properties; pasting properties

\section{INTRODUCTION}

Cocoyams (Colocasia spp. and Xanthosoma spp.) are underutilized root and tuber crop, widely distributed in many continents of the world; including Africa and Asia. They are potential crop for addressing regional rise in food shortage of Africa countries (Kumoro et al., 2014). According to FAO ( 2019), Africa has been underscored as a continent with the highest prevalence of hunger and under nourishment in the world. The publication revealed that a little over 243 million people (27.4\% of the population) suffer from hunger and the affected population is expected to increase in the near future since various governmental effort of the affected nations are still below millennium developmental goal (MDG) number two: to strive for zero hunger by 2030. Annual production of cocoyam now exceeds $10.6 \mathrm{Mt}$, of which Africa alone accounted for more than $60 \%$ of the total production (Thome et al., 2019). The average composition of cocoyam is 6.5$78 \%$ moisture, $0.2-1.1 \%$ fat, $2-5 \%$ crude fibre, $2-5 \%$ ash, $0.3-4.8 \%$ protein and 14-23\% carbohydrates (Aricı et al., 2016). It also has high starch content (70$80 \%$ ) than other underutilized tuber crops (Himeda et al., 2014). In recent years, consumption and utilization of cocoyam for diverse nutritious products mostly as gluten free flour for potentially allergic individual and toddlers suffering from enteric ailments has been linked to the small granule sizes which also contribute to its digestibility (Adane $\boldsymbol{e t}$ al., 2013). All crops have limited post-harvest lives which vary depending on the crop physiology and storage conditions. Cocoyam have low shelf life after harvest due to high moisture content, careful processing of its tubers will reduce post-harvest losses and increase utilization in other products (Himeda et al., 2014). Using different varieties of cocoyam in the production of commonly consumed West African stiff dough 'amala' (WASDA) while maintaining low oxalate and high pasting properties may show a great potential in reducing postharvest losses of cocoyam to address regional food demand in Africa. The use of processing such as soaking method to produce flour of improved characteristics and acceptable products depend on the functional profiles of the flour (Jimoh et al., 2009). Many studies on utilization of different crops for WASDA have been reported using; trifoliate yam (Abiodun and Akinoso, 2015), unripe plantain (Ilelaboye and Ogunsina, 2018), water yamcassava flour (Wireko-manu et al., 2014), white and water yam (Obadina et al., 2014) but no data have been reported for cocoyam. Therefore, the objectives of this study were to determine physicochemical and functional characteristic of the flour from cocoyam varieties soaked for $0-24 \mathrm{~h}$ at $30 \pm 2{ }^{\circ} \mathrm{C}$, and subsequently investigate sensory and physical stability of WASDA for ease of application in food processing.

\section{MATERIALS AND METHODS}

\section{Sources of raw materials}

Freshly harvested tubers of Colocasia spp. (white-fleshed) and Xanthosoma spp. corms were collected from demonstration plots in Obantoko, Abeokuta, while commercial white yam flour was obtained from local market, Bodija, Ibadan, Nigeria.

\section{Methods}

\section{Processing of cocoyam flour and WASDA}

The healthy cocoyam tubers were peeled and sliced manually with stainless knife into $3 \mathrm{~mm}$ thickness. The sliced tubers were blanched in $2000 \mathrm{~mL}$ container at 60 ${ }^{\circ} \mathrm{C}$ for $15 \mathrm{~min}$. and soaked in blanched water $(0,12$ and $24 \mathrm{~h}$.) with the lid intact at ambient temperature $\left(30 \pm 2{ }^{\circ} \mathrm{C}\right.$ ) (Abiodun and Akinoso, 2015). The tubers were drained, dried in the oven (OV-160 BS, Cheshire, England) at $60{ }^{\circ} \mathrm{C}$ for 36 h., milled (Hammer mill II, Romer labs, USA) and sieved (600 $\mu \mathrm{m}$ mesh size). The moisture content of the flour samples was in the range of $5.79-6.55 \%$ (w.b.). The flours were packed in transparent polyethylene bag and stored (Madison product, WI) at $4{ }^{\circ} \mathrm{C}$ until analyses were performed.

\section{Preparation of WASDA from flours}

Fifty grams of cocoyam/ commercial white yam flours was stirred in $150 \mathrm{~mL}$ boiling water until gelatinised. The gelatinised paste was left to cook for $5 \mathrm{~min}$ with constant stirring. The pastes were wrapped in polyethylene films (Figure 1) and left inside $1.50 \mathrm{~mL}$ round plastic food warmer (Thermolineo, Celplas, Nigeria) until sensory evaluation was conducted. 


\section{Color evaluation and $\mathrm{pH}$}

Color of the flour samples were carried out using Hunter colorimeter (D 25 Reston, Va, USA) and L*, a* and $\mathrm{b}^{*}$ values were recorded. The hand held $\mathrm{pH}$ meter (AMT03, China) was used to measure $\mathrm{pH}$ of $10 \%$ flour-water suspension (w/v) in $100 \mathrm{~mL}$ beaker. The suspension was allowed to settled for $15 \mathrm{~min}(30 \pm 2$ ${ }^{\circ} \mathrm{C}$ ) prior to measurement based on the procedure of AACC (2000).

Determination of total starch, amylose and amylopectin contents of flour

Total starch (TS) content was analysed using AACC (2000) enzymatic hydrolysis method. D-gluconate obtained from the reaction was measured from the absorbance at $510 \mathrm{~nm}$ and the results were expressed as \% of flour weight The standard AACC procedure 61e03.01 was adopted for amylose and amylopectin determination.

\section{Determination of swelling power and bulk density of flour}

Swelling power was determined following the procedure of Ilelaboye and Ogunsina (2018) and the results were expressed as the ratio of volume occupied before and after swelling. Bulk density was determined as the ratio of weight $(\mathrm{g})$ per unit volume $(\mathrm{ml})$ of the samples after tapping on a fiber board (Lawal and Akinoso, 2019)

\section{Determination of Water absorption capacity (WAC), gelling point and wettability}

Water absorption capacity (WAC) was based on ability of flour sample (1 g) suspended in excess distilled water $(10 \mathrm{~mL})$ to absorb water. The resulting sediment after decantation of supernatant was weighed and WAC was calculated by expressing gain in weight as a percentage of original weight (Lawal and Akinoso, 2019). Gelling point of flours was determined by the method of Obadina et al. (2014) as temperature above which the sample began to gel and this was recorded $30 \mathrm{sec}$ after gelatinization was visually noticed. The method described by Ilelaboye and Ogunsina (2018) was used to determine the wettability of the cocoyam flours.

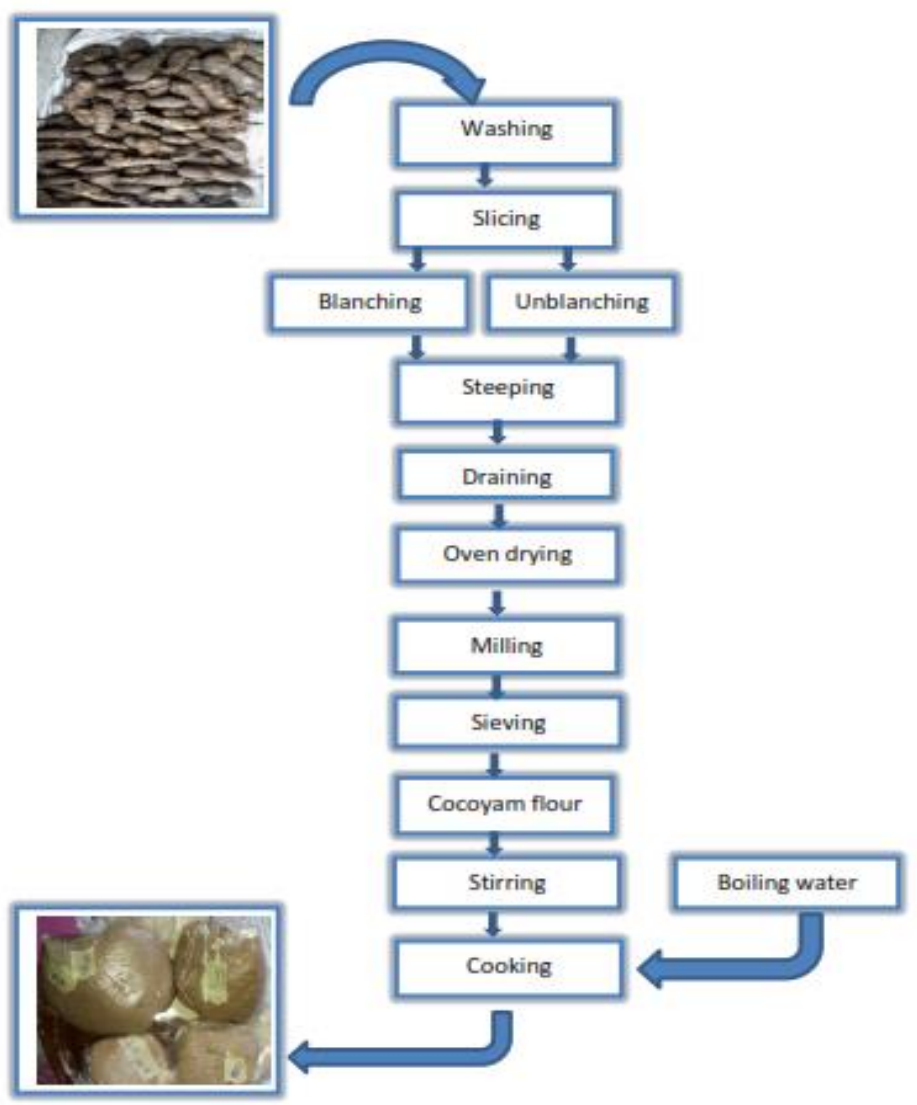

Figure 1 Flow diagram for production of West African stiff dough 'amala' (WASDA)

\section{Pasting properties}

The pasting properties of flours were measured using a rheometer (DHR-2, TA Delaware, USA). Flour sample ( $3 \mathrm{~g}$ ) was weighed in the canister and required amount of water to obtain $14 \mathrm{~g}$ flour/100 $\mathrm{g}$ was dispensed in the canister containing the sample. The mixture stirred and canister inserted into RVA. The slurry was held at $50{ }^{\circ} \mathrm{C}$ for $1 \mathrm{~min}$ and then heated to $95{ }^{\circ} \mathrm{C}$ for $5 \mathrm{~min}$, followed by cooling to $50{ }^{\circ} \mathrm{C}$ with $2 \mathrm{~min}$ holding time. The heating and cooling were carried out at constant rate $\left(11.25^{\circ} \mathrm{C} / \mathrm{min}\right)$. The pasting parameters recorded were pasting time, pasting temperature, peak viscosity, holding strength, breakdown viscosity, final viscosity and setback viscosity.

\section{Sensory properties and physical stability of WASDA}

WASDA samples obtained from different processed cocoyam and commercial white yam flours (Figure 1) were subjected to sensory evaluation using 50 semitrained panelists selected from the students of University of Ibadan, Nigeria. The panelists (already familiar with WASDA products) evaluated the samples using hedonic preference scale. The physical stability was carried out on WASDA to assess the deterioration in sensory attributes over a period of $14 \mathrm{~h}$ storage in a food warmer. This was carried out at interval of $2 \mathrm{~h}$.

\section{Statistical analysis}

The design of experiment was a $3 \times 2$ factorial. The factors and their levels were soaking period $\left(0,12\right.$ and $24 \mathrm{~h}$ after peeling at ambient conditions $30 \pm 2{ }^{\circ} \mathrm{C}$ ), and cocoyam varieties (Colocasia spp. and Xanthosoma spp.). All the data obtained were subjected to an analysis of variance (ANOVA) and Duncan multiple range tests were used to separate the means at $5 \%$ level of significance (SPSS 16.0)

\section{RESULTS AND DISCUSSION}

\section{Physicochemical properties of flours}

Soaking processes significantly $(\mathrm{p}<0.05)$ affected the color of the cocoyam varieties (Table 1). Colocasia spp. had higher mean L* (lightness) values (71.41 75.33) than Xanthosoma spp. (66.68-71.02). The $\mathrm{L}^{*}$ values also increased with increase in soaking time $(0-24 \mathrm{~h})$ for the two varieties. The highest $\mathrm{L}^{*}$ value of flours produced from Colocasia spp. soaked for $24 \mathrm{~h}$ (Col 24) suggested a better quality for its flours and starches. The $\mathrm{L}^{*}$ values of the flours recorded are lower than the range 74.80-82.90 reported for sun and oven dried Colocasia spp. flours at different maturity (Himeda $\boldsymbol{e t}$ al., 2014). The lower L* values are pointer to discoloration which could be due to variation in drying process, varieties and phenol content of the flours (Lawal and Akinoso, 2019). The a* values of the flour ranged from -13.26 ( Col 12) to -9.76 (Xan 12), while the $b^{*}$ ranged from $12.42(\mathrm{Col} 24)$ to $15.37(\mathrm{Col} 0)$. The $-\mathrm{a}^{*}$ and $+\mathrm{b}^{*}$ values correspond to green and yellow colors, respectively. The $a^{*}$ values decreased with the increase in soaking time for the two varieties while the $b^{*}$ values of Colocasia spp. followed similar trend. Higher $\mathrm{b}^{*}$ value (15.37) of $\mathrm{Col} 0$ flour is an indication of higher carotene pigment. Yellow intensity is linked to the concentration of beta carotene pigment in food (Jimoh et al., 2009).

Mean values for $\mathrm{pH}$ contents ranged between 5.87 (Xan 12) and 6.45 (Col 12) (Table 1). These values were close to the amounts (5.10-6.40) reported for different soaked flours of white and water yams (Obadina et al., 2014). As expected, soaking for 12 and $24 \mathrm{~h}$ reduced the $\mathrm{pH}$ of the Xanthosoma spp. flour by 3.45 and $2.47 \%$, respectively. According to Obadina et al. (2014) $\mathrm{pH}$ reduction is an indication of improved shelf stability in flours and products. Total starch content of the flours from unsoaked and soaked cocoyam varieties ranged from 63.22 to $70.32 \%$ and 11.24 to $22.39 \%$, respectively (Table 1). The starch and amylose contents varied significantly $(\mathrm{p}<0.05)$ between the unsoaked and soaked cocoyam flours. For Xanthosoma spp., the starch and amylose contents were higher in the soaked cocoyam flours. High amylose content means higher apparent viscosity as this suggests that soaking induced transport of water molecule into granule, including hydration of both crystalline and amorphous rings which could accompanied by leaching out of starch chains and the consequent increase in dispersion viscosity (Obadina et al., 2014). Wirekomanu et al. (2014) indicated that crops of different botanical origin grown in Ashanti, Ghana have variable amylose content. Amylopectin content ranged from 77.61 (Col 12) to $88.76 \%$ (Xan 12). The starch contents observed were within the range (58.50-68 .80\%) reported for taro flours (Arıcı et al., 2016). The high amylose content recorded for cocoyam flours indicate their importance for improving mealiness. Starches with high amylose content are highly value for low glycemic index in starch based products for diabetic and hyperlipidemia patient (Otegbayo et al., 2012). 
Table 1 Physicochemical properties of cocoyam flours

\begin{tabular}{lccccccc}
\hline CYF & $\mathrm{L}^{*}$ & $\mathrm{a}^{*}$ & $\mathrm{~b}^{*}$ & $\mathrm{pH}$ & $\begin{array}{c}\text { Total starch } \\
\text { content }(\%)\end{array}$ & $\begin{array}{c}\text { Amylose } \\
\text { content }(\%)\end{array}$ & $\begin{array}{c}\text { Amylopectin } \\
\text { content }(\%)\end{array}$ \\
\hline Xan 0 & $67.75^{\mathrm{c}} \pm 1.92$ & $-10.99^{\mathrm{b}} \pm 0.32$ & $12.95^{\mathrm{d}} \pm 0.38$ & $6.08^{\mathrm{d}} \pm 0.01$ & $19.05^{\mathrm{b}} \pm 0.10$ & $12.51^{\mathrm{d}} \pm 0.03$ & $87.49^{\mathrm{c}} \pm 0.04$ \\
Xan 12 & $66.68^{\mathrm{c}} \pm 0.78$ & $-9.76^{\mathrm{a}} \pm 0.08$ & $14.22^{\mathrm{b}} \pm 0.24$ & $5.87^{\mathrm{f}} \pm 0.01$ & $13.22^{\mathrm{f}} \pm 0.04$ & $11.24^{\mathrm{f}} \pm 0.03$ & $88.76^{\mathrm{a}} \pm 0.03$ \\
Xan 24 & $71.02^{\mathrm{b}} \pm 0.72$ & $-10.91^{\mathrm{b}} \pm 0.11$ & $13.33^{\mathrm{c}} \pm 0.15$ & $5.93^{\mathrm{e}} \pm 0.01$ & $18.85^{\mathrm{c}} \pm 0.04$ & $11.57^{\mathrm{e}} \pm 0.06$ & $88.43^{\mathrm{b}} \pm 0.06$ \\
Col 0 & $71.41^{\mathrm{b}} \pm 0.37$ & $-12.03^{\mathrm{c}} \pm 0.01$ & $15.37^{\mathrm{a}} \pm 0.21$ & $6.10^{\mathrm{c}} \pm 0.01$ & $16.52^{\mathrm{e}} \pm 0.06$ & $17.00^{\mathrm{c}} \pm 0.23$ & $83.00^{\mathrm{d}} \pm 0.23$ \\
Col 12 & $76.52^{\mathrm{a}} \pm 0.31$ & $-13.26^{\mathrm{e}} \pm 0.08$ & $13.44^{\mathrm{c}} \pm 0.05$ & $6.45^{\mathrm{a}} \pm 0.01$ & $18.08^{\mathrm{d}} \pm 0.26$ & $22.39^{\mathrm{a}} \pm 0.17$ & $77.61^{\mathrm{f}} \pm 0.17$ \\
Col 24 & $75.33^{\mathrm{a}} \pm 1.20$ & $-13.06^{\mathrm{de}} \pm 0.23$ & $12.42^{\mathrm{e}} \pm 0.12$ & $6.23^{\mathrm{b}} \pm 0.01$ & $20.32^{\mathrm{a}} \pm 0.07$ & $20.15^{\mathrm{b}} \pm 0.10$ & $79.85^{\mathrm{e}} \pm 0.10$ \\
\hline
\end{tabular}

Values with the same letter in a column are not significantly different at 0.05 probability level.

Legend: CYF: Cocoyam yam flour; L*a*b*: Color parameters; Xan 0, Xan 12, Xan 24, Col 0, Col 12, Col 24: Xanthosoma spp. and Colocasia spp. soaked for 0,12 and $24 \mathrm{hrs}$ respectively.

\section{Functional properties of flours}

Swelling power of the flours samples ranged from 2.60 to $6.20 \%$ (Table 2). The highest value was determined for Colocasia spp. while the minimum value was found in Xanthosoma spp. (soaked for 12hrs). For Xanthosoma spp. soaking reduced the swelling power of the flours significantly by 1.77 and 1.44 folds at 12 at $24 \mathrm{~h}$, respectively, while the flours of Xanthosoma were not affected by the soaking time. This could be attributed to influence of crop varieties. Ilelaboye and Ogunsina (2018) reported swelling power to be a function of crop varieties, amylose content and loose structure of granules. The bulk density of flours varied significantly $(p<0.05)$ between 0.77 and $0.90 \mathrm{~g} / \mathrm{ml}$ (Table 2) for the flours obtained from the unsoaked and soaked $(12 \mathrm{~h})$ Colocasia spp. corm. The flours of Col 12 had higher bulk density than other flours regardless of soaking time and varieties. The value is also higher than $(0.689 \mathrm{~g} / \mathrm{ml})$ that was observed by Kaushal et al. (2012) for taro flours in India. Bulk density decreased with soaking time by about $3.5 \%$ for Xan 12 while it increased with soaking time by about $16.90 \%$ for Col 12. According to Obadina et al. (2014) high and low bulk densities of flours is indication of their suitability in food preparation and complementary foods, respectively. Thus, high bulk density of Col 12 flours implies its suitability in the production of food thickener. The result of Water absorption capacity (WAC) ranged from 10.84 ( $\mathrm{Col} \mathrm{0}$ ) to $21.89 \%$ (Xan 12). The soaked Xan 12 flour had higher WAC than soaked Colocasia flours and was significantly different $(\mathrm{p}<0.05)$ from other flours. Generally, $12 \mathrm{~h}$ soaking time gave the best WAC for the two varieties which was higher than their unsoaked flours by 1.49 (Xanthosoma spp.) and 1.06 folds (Colocasia spp.). According to Kaushal et al. (2012) flours with high WAC are known for hydrophilic constituents, which enable retention of more water for good handling. The high WAC of flours observed from soaked corms suggests that such flours may be exploited in food products where good viscosity is required. Wettability is the ease of dispersing flour samples and technically linked to capillary action which aided liquid penetration into porous body in water (Obadina et al., 2014). The wettability for different flours varied from 41.67 to 238.675 seconds. The highest and lowest values were observed for $\mathrm{Col} 0$ and Xan 12 flours, respectively. The lowest wettability of Xan 12 flour is potentially useful in reconstitution of flours in water, especially for products that that require immediate reconstitution.

Table 2 Functional properties of cocoyam flours

\begin{tabular}{lccccc}
\hline CYF & $\begin{array}{c}\text { Swelling } \\
\text { power }\end{array}$ & $\begin{array}{c}\text { Bulk density } \\
(\mathrm{g} / \mathrm{mL})\end{array}$ & $\begin{array}{c}\text { WAC } \\
(\%)\end{array}$ & $\begin{array}{c}\text { Gelling point } \\
\left({ }^{\circ} \mathrm{C}\right)\end{array}$ & $\begin{array}{c}\text { Wettability } \\
(\mathrm{s})\end{array}$ \\
\hline Xan 0 & $0.46^{\mathrm{a}} \pm 0.01$ & $0.87^{\mathrm{b}} \pm 0.01$ & $14.66^{\mathrm{cd}} \pm 1.94$ & $88.67^{\mathrm{a}} \pm 1.15$ & $110.00^{\mathrm{c}} \pm 42.67$ \\
Xan 12 & $0.26^{\mathrm{d}} \pm 0.01$ & $0.84^{\mathrm{b}} \pm 0.01$ & $21.89^{\mathrm{a}} \pm 0.28$ & $86.00^{\mathrm{b}} \pm 0.00$ & $41.67^{\mathrm{d}} \pm 10.69$ \\
Xan 24 & $0.32^{\mathrm{c}} \pm 0.01$ & $0.84^{\mathrm{c}} \pm 0.01$ & $17.88^{\mathrm{bc}} \pm 3.24$ & $82.00^{\mathrm{c}} \pm 0.00$ & $89.33^{\mathrm{cd}} \pm 51.54$ \\
Col 0 & $0.62^{\mathrm{a}} \pm 0.01$ & $0.77^{\mathrm{d}} \pm 0.01$ & $10.84^{\mathrm{d}} \pm 0.23$ & $80.00^{\mathrm{d}} \pm 0.00$ & $238.67^{\mathrm{ab}} \pm 29.74$ \\
Col 12 & $0.62^{\mathrm{a}} \pm 0.01$ & $0.90^{\mathrm{a}} \pm 0.01$ & $11.48^{\mathrm{d}} \pm 1.03$ & $80.00^{\mathrm{d}} \pm 0.00$ & $234.67^{\mathrm{ab}} \pm 57.84$ \\
Col 24 & $0.62^{\mathrm{a}} \pm 0.01$ & $0.83^{\mathrm{c}} \pm 0.01$ & $10.94^{\mathrm{d}} \pm 1.29$ & $80.00^{\mathrm{d}} \pm 0.00$ & $188.67^{\mathrm{b}} \pm 7.09$ \\
\hline
\end{tabular}

Values with the same letter in a column are not significantly different at 0.05 probability level.

Legend: CYF: Cocoyam yam flour; Xan 0, Xan 12, Xan 24, Col 0, Col 12, Col 24: Xanthosoma spp. and Colocasia spp. soaked for 0,12 and 24 hrs, respectively.

The gelling point of the flours varied from 80.00 to $88.67{ }^{\circ} \mathrm{C}$. Unsoaked and soaked Xanthosoma spp. flours gave highest gelling point than their respective Colocasia spp. The gelling point of Xanthosoma spp. flours decreased significantly $(\mathrm{p}<0.05)$ with increase in soaking time from $0-12 \mathrm{~h}$ and $0-24 \mathrm{~h}$ by 3.01 and $7.52 \%$ respectively. This implied low energy and good product stability for the soaked Xanthosoma spp. flours. Other food components such as fats and proteins may elongate gel formation thereby reducing swelling and increasing energy consumption needed to overcome barrier (Kaushal et al., 2012). The results of gelling points in this study are within the range $69.20-91.70{ }^{\circ} \mathrm{C}$ reported for Colocasia spp. with variable maturity indices and drying methods (Himeda $e$ al., 2014)

\section{Pasting properties of cocoyam flour}

The Rapid Visco Analyzer (RVA) pasting properties of unsoaked and soaked cocoyam flours are presented in Table 3. There were significant differences $(p<0.05)$ among the flour samples during heating and cooling cycles in the RVA test. Peak, holding strength and final viscosities varied from 2156.67 to 5118.67 $\mathrm{cp}, 2104.67$ to $4102.67 \mathrm{cp}$ and 51.33 to $705.00 \mathrm{cp}$, respectively. The unsoaked flour of Xanthosoma spp. (Xan 0) had lower peak, holding strength and breakdown viscosities than all other flours. Generally, soaked flours showed higher viscosities than their corresponding unsoaked flours. Colocasia spp. soaked for $12 \mathrm{~h}$ ( Col 12) gave highest peak and holding viscosities while $24 \mathrm{~h}$ ( Col 24) showed highest breakdown viscosity. The observed increase in viscosities of the soaked corms flours could be attributed to higher flour-water interaction and weaker cohesive forces that could easily disintegrate on heating. The weak cohesive forces observed from flours with high peak viscosities are useful for high gel foods (Otegbayo et al., 2012). The good holding strength may prove useful for low cooking loss and superior eating quality (Aricı et al., 2016). The lower breakdown of unsoaked flours signifies higher stability of the flour under hot condition in comparison to the flours from the soaked corms. Wirekomanu et al. (2014) stated that break down values is inversely related to heat stress resistivity during cooking. The final and setback viscosities ranged from 2966.67 to $6445.33 \mathrm{cp}$ and 860.33 to $2343.67 \mathrm{cp}$, respectively. As noted earlier, final and setback viscosities showed higher values for soaked flours samples compared with unsoaked flours. The higher setback values of soaked flours is an indication of lower retrogradation tendencies for soaked cocoyam products. According to Kaushal et al. (2012) final viscosity is related to the ease of viscous paste formation after cooking. All the flours have higher final than peak viscosities regardless of the soaking duration. Higher value of final viscosity than peak viscosity had been reported to be a good indicator of increasing tendency for flour retrogradation. The high value of final viscosity had also been attributed to the alignment of amylose chain by Arıc et al. (2016). Pasting time and temperature of the flours provide information of the minimum time and heat needed to form paste, since granules mix, imbibe water to swell freely in the presence of heat (Wireko-manu et al., 2014). The values (pasting time and temperature) ranged from 5.61 to $6.29 \mathrm{~min}$ and 86.37 to $88.92{ }^{\circ} \mathrm{C}$. Significant decreased $(\mathrm{p}<0.05)$ was observed in pasting time and temperature with soaking time.

Table 3 Pasting properties of cocoyam flours

\begin{tabular}{llllllll} 
CYF & PV $(\mathrm{cP})$ & HS $(\mathrm{cP})$ & $\mathrm{BV}(\mathrm{cP})$ & $\mathrm{FV}(\mathrm{cP})$ & $\mathrm{SV}(\mathrm{cP})$ & $\mathrm{PT}(\mathrm{s})$ & $\mathrm{PM}\left({ }^{\circ} \mathrm{C}\right)$ \\
\hline
\end{tabular}




\begin{tabular}{lccccccc}
\hline Xan 0 & $2156.67^{\mathrm{f}} \pm 1.15$ & $2104.67^{\mathrm{f}} \pm 0.58$ & $51.33^{\mathrm{e}} \pm 0.58$ & $2966.67^{\mathrm{e}} \pm 1.53$ & $860.33^{\mathrm{e}} \pm 0.58$ & $6.14^{\mathrm{b}} \pm 0.01$ & $88.92^{\mathrm{a}} \pm 0.03$ \\
Xan 12 & $3345.00^{c} \pm 1.00$ & $3242.67^{\mathrm{c}} \pm 1.15$ & $102.67^{\mathrm{d}} \pm 1.15$ & $4454.00^{\mathrm{b}} \pm 1.00$ & $1213.33^{\mathrm{c}} \pm 0.58$ & $6.13^{\mathrm{b}} \pm 0.01$ & $88.02^{\mathrm{b}} \pm 0.03$ \\
Xan 24 & $2501.33^{\mathrm{d}} \pm 0.58$ & $2342.67^{\mathrm{e}} \pm 1.53$ & $160.67^{\mathrm{c}} \pm 1.15$ & $3281.00^{\mathrm{d}} \pm 1.00$ & $938.67^{\mathrm{d}} \pm 0.58$ & $5.61^{\mathrm{d}} \pm 0.01$ & $88.12^{\mathrm{b}} \pm 0.03$ \\
Col 0 & $2484.00^{\mathrm{e}} \pm 1.00$ & $2407.00^{\mathrm{d}} \pm 1.00$ & $77.67^{\mathrm{e}} \pm 0.58$ & $3806.00^{\mathrm{c}} \pm 1.00$ & $1400.33^{\mathrm{b}} \pm 0.58$ & $6.20^{\mathrm{a}} \pm 0.01$ & $86.43^{\mathrm{c}} \pm 0.12$ \\
Col 12 & $5118.67^{ \pm} \pm 0.58$ & $4102.67^{\mathrm{a}} \pm 1.15$ & $1017.67^{\mathrm{a}} \pm 1.15$ & $6445.33^{\mathrm{a}} \pm 1.53$ & $2342.33^{\mathrm{a}} \pm 0.58$ & $5.41^{ \pm} \pm 0.01$ & $86.37^{\mathrm{c} \pm 0.06}$ \\
Col 24 & $4503.00^{\mathrm{b}} \pm 1.00$ & $3798.33^{\mathrm{b}} \pm 1.15$ & $705.00^{\mathrm{b}} \pm 1.00$ & $6144.00^{\mathrm{a}} \pm 1.00$ & $2343.67^{\mathrm{a}} \pm 0.58$ & $5.81^{\mathrm{c}} \pm 0.01$ & $87.53^{\mathrm{b}} \pm 1.07$ \\
\hline
\end{tabular}

Values with the same letter in a column are not significantly different at 0.05 probability level.

Legend: CYF: Cocoyam yam flour; Xan 0, Xan 12, Xan 24, Col 0, Col 12, Col 24: Xanthosoma spp. and Colocasia spp. soaked for 0,12 and 24 hrs, respectively; PV: Peak viscosity; HS: Holding strength; BV: Breakdown viscosity; FV: Final viscosity; SV: Setback viscosity; PT: Pasting time; PM: Pasting temperature

\section{Sensory properties of WASDA}

The sensory properties of WASDA samples varied with the soaking time of cocoyam corms (Table 4). Generally, aroma and mouldability of WASDA decreased slightly with increase in soaking time. The score ranged from 4.31 to 6.71 and 5.06 to 6.71 , respectively. The control WYF showed significantly higher values which may be attributed to different botanical origin of the crops. However there were no significant differences $(\mathrm{p}>0.05)$ between Xan 0 and Xan 24; $\mathrm{Col} 0$ and $\mathrm{Col} 12$ WASDA. Col 12 and Xan 24 showed slightly higher color score compared to WASDA from other cocoyam flours but the values were not significantly different from unsoaked samples. According to Jimoh et al. (2009), brown color of the WASDA is an important determinant of the product acceptability among the Yoruba's in the West Africa and also attributed color formation to enzymatic browning of yam, drying condition and plant species. Expectedly, WASDA from the control (WYF) also showed higher color score than cocoyam flours. This is in agreement with findings of Abiodun and
Akinoso (2015) on stiff dough from yam. The textural score of WASDA ranged from 5.17 (Xan 12) to 8.14 (WYF). There were no significant difference between Xan 0 and Xan 24; $\mathrm{Col} 0$ and $\mathrm{Col}$ 12. The WASDA from control (WYF) was significantly higher than the cocoyam based products and this could be attributed to the physiology of white yam. Although WASDA of Xan 24 had higher taste, the sensory score was not significantly different $(\mathrm{p}>0.05)$ from the Xan 0 . The Col 12 had the highest taste of all the cocoyam based WASDA but the score was significantly lower $(\mathrm{p}<0.05)$ than the control (WYF). This could be attributed to anti-nutrient content (oxalate) of cocoyam that has been implicated in slight bitter taste (Kumoro et al., 2014). Generally, control WASDA (produced from commercial white yam flour) had the highest overall acceptability which was followed by Xan 24 and $\mathrm{Col} 12$. The findings in this study revealed that WASDA obtained from soaked (12 h for Colocasia spp. and $24 \mathrm{~h}$ for Xanthosoma spp.) cocoyam flours could be alternative to commonly consumed white yam flour.

Table 4 Mean sensory scores of WASDA prepared from cocoyam and white yam flours

\begin{tabular}{lcccccc}
\hline WASDA & Color & Aroma & Texture & Mouldability & Taste & $\begin{array}{c}\text { Overall } \\
\text { acceptability }\end{array}$ \\
\hline Xan 0 & $5.54^{\mathrm{cd}} \pm 1.20$ & $6.71^{\mathrm{b}} \pm 1.56$ & $6.23^{\mathrm{bc}} \pm 2.04$ & $6.09^{\mathrm{bcd}} \pm 1.27$ & $5.86^{\mathrm{cd}} \pm 1.68$ & $5.94^{\mathrm{b}} \pm 1.37$ \\
Xan 12 & $5.40^{\mathrm{cd}} \pm 2.06$ & $5.29^{\mathrm{d}} \pm 1.86$ & $5.17^{\mathrm{d}} \pm 1.89$ & $5.49^{\mathrm{de}} \pm 2.16$ & $5.00^{\mathrm{d}} \pm 1.77$ & $5.60^{\mathrm{b}} \pm 1.80$ \\
Xan 24 & $6.09^{\mathrm{bc}} \pm 1.96$ & $6.43^{\mathrm{bc}} \pm 1.61$ & $6.40^{\mathrm{bc}} \pm 2.29$ & $5.49^{\mathrm{de}} \pm 2.16$ & $5.97^{\mathrm{bc}} \pm 1.99$ & $6.34^{\mathrm{b}} \pm 2.01$ \\
Col 0 & $6.60^{\mathrm{bc}} \pm 1.48$ & $6.43^{\mathrm{bc}} \pm 1.61$ & $6.51^{\mathrm{bc}} \pm 1.76$ & $6.71^{\mathrm{b}} \pm 1.64$ & $6.06^{\mathrm{bc}} \pm 1.51$ & $5.91^{\mathrm{b}} \pm 1.63$ \\
Col 12 & $6.89^{\mathrm{b}} \pm 1.51$ & $5.49^{\mathrm{cd}} \pm 1.98$ & $6.14^{\mathrm{c}} \pm 1.87$ & $6.57^{\mathrm{bc}} \pm 1.79$ & $6.51^{\mathrm{bc}} \pm 1.38$ & $6.34^{\mathrm{b}} \pm 1.45$ \\
Col 24 & $5.14^{\mathrm{d}} \pm 1.73$ & $4.31^{\mathrm{e}} \pm 1.98$ & $5.17^{\mathrm{d}} \pm 1.89$ & $5.06^{\mathrm{e}} \pm 2.09$ & $3.66^{\mathrm{e}} \pm 2.06$ & $4.71^{\mathrm{c}} \pm 1.72$ \\
WYF & $7.69^{\mathrm{a}} \pm 0.80$ & $7.83^{\mathrm{a}} \pm 0.92$ & $8.14^{\mathrm{a}} \pm 0.91$ & $7.94^{\mathrm{a}} \pm 0.84$ & $7.54^{\mathrm{a}} \pm 0.92$ & $8.06^{\mathrm{a}} \pm 0.73$ \\
\hline
\end{tabular}

Values with the same letter in a column are not significantly different at 0.05 probability level.

Legend: Xan 0, Xan 12, Xan 24, Col 0, Col 12, Col 24 WASDA: from Xanthosoma spp. and Colocasia spp. flours soaked for 0,12 and 24 hrs, respectively; WYF: White yam WASDA.

\section{Physical stability of WASDA}

The results of the analysis of the physical stabilities of different WASDA samples are shown in Figure 2. A significant decrease $(p<0.05)$ was observed among the values. The textural stabilities of freshly prepared WASDA ranged from 5.17 to 8.14 and the values decreased (8.02-2.24) steadily with the storage time (2-12 h). This suggests an increase in retrogradation with increased storage time. Otegbayo et al. (2012) had attributed higher retrogradation to higher ratio of final to peak viscosities. The different soaking period did not affect textural stability of WASDA from the two varieties of cocoyam beyond $12 \mathrm{~h}$. The control (white yam) WASDA showed significantly $(\mathrm{p}<0.05)$ higher value $(4.86-8.14)$ than all the cocoyam based WASDA (2.26-6.23). This is not unconnected with the fact the WASDA from white yam is highly value for texture by Yoruba's in Nigeria. Abiodun and Akinoso (2015) observed significantly higher textural stability for white yam WASDA compared with trifoliate yam based WASDA. Also, increase in storage time bought about a decrease in aroma and color of WASDA. The aroma of WASDA from unsoaked and soaked cocoyam flour ranged from 2.18 to 6.71 and 2.04 to 6.43 for Xanthosoma spp.; 1.96 to 5.89 and 1.99 to 5.49 for Colocasia spp., respectively while the aroma ranged from 2.15 to 5.54 and 2.06 to 6.05 for Xanthosoma spp.; 2.02 to 6.60 and 2.13 to 6.89 for Colocasia spp., respectively. Aroma and color values decreased with the storage time. The lower values recorded with storage time were an indication of samples instability. Although the WASDA from Xan 24, Col 0 and $\mathrm{Col} 12$ showed higher values for aroma and color among all cocoyam flours, they were not acceptable beyond $10 \mathrm{~h}$ of storage. The Reduction in stability could be attributed to the increased activities of spoilage organisms as the storage time increases. Olatoye and Lawal (2016) attributed storage instability of plantain products to microbial growth and fermentation process. Soaking of cocoyam prior to drying was observed to improve stability of WASDA.

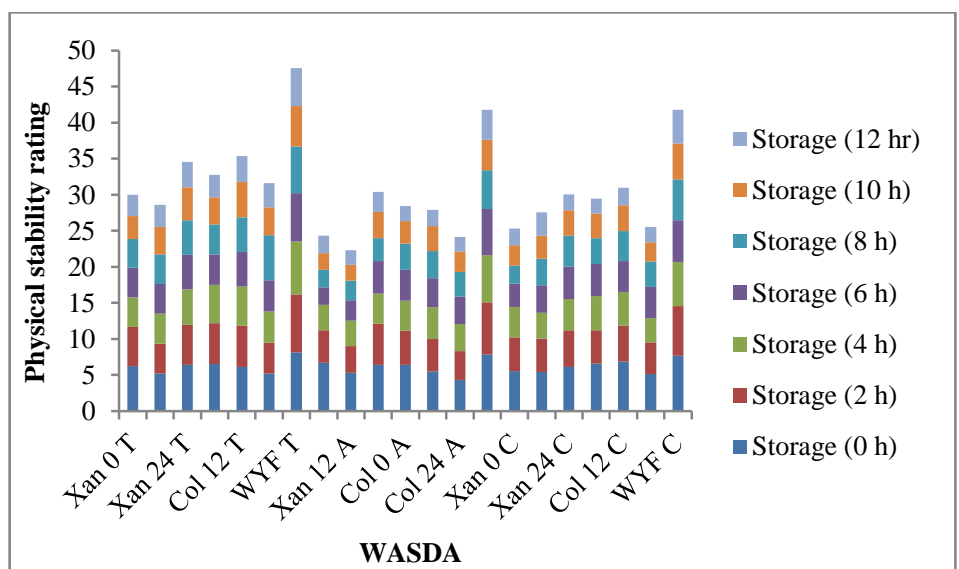

Figure 2 Physical stability of WASDA from the flour Samples (Xan 0, Xan 12 Xan 24, Col 0, Col 12, Col 24) T, A, C: Physical stability rating for different WASDA texture, aroma and color respectively.

\section{CONCLUSION}

The two varieties of cocoyam (Colocasia spp. and Xanthosoma spp) had a great utilization potential in producing good quality flours for acceptable West African stiff dough 'amala' (WASDA). The physical, functional and pasting properties of the flours increased with the soaking process, which are advantageous in stiff dough production. Sensory evaluation result showed that WASDA obtained from soaked cocoyam flours at $12 \mathrm{~h}$ (Colocasia spp.) and $24 \mathrm{~h}$ (Xanthosoma spp.) were mostly acceptable and comparable very well to that from white yam. The physical stability of WASDA was established at $10 \mathrm{~h}$ storage.

Conflicts of interest: No conflict of interest is declared. 


\section{REFERENCES}

AACC. (2000). Approved Methods of the American Association of Cereals Chemists. In American Association of Cereal Chemists, St, Paul, MN.

Abiodun, O. A., \& Akinoso, R. (2015). Textural and sensory properties of trifoliate yam (Dioscorea dumetorum) flour and stiff dough 'amala.' Journal of Food Science and Technology, 52(5), 2894-2901. http://dx.doi.org/10.1007/s13197-014-1313-y

Adane, T., Shimelis, A., Negussie, R., Tilahun, B., \& Haki, G. D. (2013). Effect of processing method on the proximate composition, mineral content and antinutritional factors of taro (Colocasia esculenta, L.) grown in Ethiopia. African Journal of Food, Agriculture, Nutrition and Development, 13(2), 73837398 .

Arıcı, M., Yıldırım, R. M., Özülkü, G., Yaşar, B., \& Toker, O. S. (2016) Physicochemical and nutritional properties of taro (Colocasia esculenta $L$ Schott) flour as affected by drying temperature and air velocity. LWT - Food

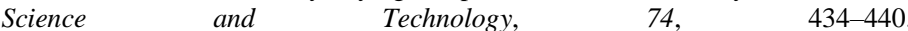
http://dx.doi.org/10.1016/j.lwt.2016.08.006

FAO. (2019). The State of Food Security and Nutrition in the World, 2019. Safeguarding against economic slowdowns and downturns, Rome, FAO. License: CC BY-NC-SA $\quad 3.0 \quad$ IGO (Vol. 10, Issue 3) https://dx.doi.org/10.26596/wn.201910395-97

Himeda, M., Njintang, Y. N., \& Gaiani, C. (2014). Physicochemical and thermal properties of taro (Colocasia esculenta) powders as affected by state of maturity and drying method. Journal of Food Science and Technology, 51(9), 1857-1865. Ilelaboye, N. O., \& Ogunsina, T. I. (2018). Proximate composition , functional properties and sensory evaluation of stiff dough (amala) prepared from Okara fortified plantain-sorghum flours. Asian Food Science, 5(1), 1-10. https://dx.doi.org/10.9734/AFSJ/2018/44093

Jimoh, K. O., Olurin, T. O., \& Aina, J. O. (2009). Effect of drying methods on the rheological characteristics and colour of yam flours. African Journal of Biotechnology, 8(10), 2325-2328.

Kaushal, P., Kumar, V., \& Sharma, H. K. (2012). Comparative study of physicochemical, functional, antinutritional and pasting properties of taro (Colocasia esculenta), rice (Oryza sativa) flour, pigeonpea (Cajanus cajan) flour and their blends. LWT - Food Science and Technology, 48(1), 59-68 https://dx.doi.org/10.1016/j.lwt.2012.02.028

Kumoro, A. C., Budiyati, C. S., \& Retnowati, D. S. (2014). Calcium oxalate reduction during soaking of giant taro (Alocasia macrorrhiza L.) Schott) corm chips in sodium bicarbonate solution. International Food Research Journal, 21(4), 1583-1588.

Lawal, A., \& Akinoso, R. (2019). Physical properties, proximate composition and antioxidant activities of aerial yam (Dioscorea bulbifera) bulbils grown in Nigeria. Acta Periodica Technologica, 50(1), 143-151. https://dx.doi.org/10.2298/apt19501431

Obadina, A. O., Babatunde, B. O., \& Olotu, I. (2014). Changes in nutritional composition, functional, and sensory properties of yam flour as a result of presoaking. Food Science and Nutrition, 2(6), 676-681 https://dx.doi.org/10.1002/fsn3.150

Olatoye, K. K., \& Lawal, A. I. (2016). Storability of "Dodolkire" (Over -ripe plantain-based snack) at ambient temperature $\left(28 \pm 2{ }^{\circ} \mathrm{C}\right)$. Agricultural Engineering International: CIGR Journal, 18(1).

Otegbayo, B. O., Robert, A., \& Bokanga, M. (2012). Effects of storage on the chemical composition and food quality of yam. Journal of Food Processing and Preservation, 36, 438-445. https://dx.doi.org/10.1111/j.1745-4549.2011.00600.x Thome, K., Mchael, D. S., Kamron, D., \& Nicholas, R. (2019). Internationa food security assessment, 2019-2029. Department of Agriculture, Economic Research Service.

Wireko-manu, F. D., Ellis, W. O., Oduro, I., \& Asiedu, R. (2014). Prediction of the suitability of water yam (Dioscorea alata) for amala product using pasting and sensory characteristics. Journal of Food Processing and Preservation, 38(1), 1339-1345

https://dx.doi.org/10.1111/jfpp.12095 